\title{
Dimensions of Job satisfaction of Teacher Educators: A Qualitative Study of the Universities of Sindh Province of Pakistan
}

\author{
Zafarullah Sahito $^{1, *}$ \& Pertti Vaisanen ${ }^{1}$ \\ ${ }^{1}$ School of Applied Educational Sciences and Teacher Education, Philosophical Faculty, University of Eastern \\ Finland, Finland \\ ${ }^{2}$ Sukkur Institute of Business Administration (SIBA), Sindh, Pakistan \\ *Correspondence: School of Applied Educational Sciences and Teacher Education, Philosophical Faculty, University \\ of Eastern Finland, Finland. E-mail: zafarullah.sahito@gmail.com
}

Received: August 3, 2016

Accepted: September 10, 2016 Online Published: September 26, 2016

doi:10.5430/jct.v5n2p43

URL: http://dx.doi.org/10.5430/jct.v5n2p43

\begin{abstract}
This research study examines the job satisfaction level and its dimensions of teacher educators-who are working at the departments, faculties and institutes of education. In-depth semi-structured interviews were conducted and field-work observations were recorded on TEs $(n=40)$, working as lecturers, assistant professors, associate professors and professors at their respective universities. Qualitative data were analysed using thematic analysis. Six themes were inductively identified: (a) work, assignments and workload; (b) opportunities for advancement, growth and development; (c) financial and fringe benefits; (d) supervisory support, permissions and free hand; (e) working and sympathetic relationships; and (f) available facilities and working environments. All themes revealed the significance and utility of the study and also explained the proper usage of findings for the benefits of organizations, faculties, departments and TEs. This article increases and advances the knowledge by revealing the values of qualitative research methods generally, and thematic analysis specifically, as a means of disseminating the evidence-based information to its readers and all stakeholders in the concerned paradigm of the job satisfaction of TEs among the universities of the Sindh province of Pakistan. This article is a suitable, reliable and strong resource for the heads of educational organizations, such as universities, institutes, faculties, departments and TEs themselves to help them to understand the real position and the dimensions of job satisfaction, which they can apply in their daily practice to make their professional and personal life easier and more meaningful.
\end{abstract}

Keywords: job satisfaction; thematic analysis; dimensions; teacher educators; professional life

\section{Introduction}

A job is a basic need and a necessity for any human being to meet the day to day expenses of their family. Satisfaction with the job leads an employee towards family satisfaction and vice versa. Employee satisfaction also increases the productivity, reputation, popularity and identification of his and his organization, too. The employee and the organization have a strong connection to each other because they are each other's mutual support and survival. Like other employees of the organization, teachers and the teacher educators (TEs) are also the employees of educational institutions, which may be universities, colleges, schools and any training institutions. The TEs work to impart education and train the teachers of the future who will shape the future of the nation at schools, colleges and universities in any country. Their satisfaction is also due with their job to improve the system of teacher education institution especially in developing countries that need quality education to steer society in the proper direction to live peacefully.

Competitive environments and situations in any organization require paying proper, active and focused attention to their human resources and encourage them to perform better to achieve satisfactory level of performance to become a thriving organization (Updegraff, 2004). At educational organizations, people, as the main resource try to ensure their excellence in performance in order to achieve organizational goals, aims and objectives (Paterson, 1999). In this regard, social and psychological factors in the working environment play a very positive and pivotal role in recruiting and retaining the employees at their workplaces in the organizations (Pors \& Johannsen, 2002). 
Furthermore, appreciation of the work done by any employee also creates job satisfaction. This has an effect on the quality of the organization's services (Rizi \& Kazempur, 2010), which grasps, the potential drivers of their employees' job satisfaction (McManus, 2003).

Job satisfaction also known as employee satisfaction is linked with the aptitude, attitude and general behaviour of a person towards their job. The multidimensional psychological responses of a person towards their job give them happiness; for example a pleasurable or positive emotional state result from the appraisal of one's job or job experiences (Locke, 1976). If an individual enjoys their job, they are likely to be content in that role (Spector, 1997). There is a combination of multidimensional psychological and personal responses, such as cognitive (evaluative), affective (emotional) and behavioral components that affect one's job satisfaction (Hulin \& Judge, 2003). Cognitive job satisfaction is objective and depends on the logical evaluations of various facets of a job. It is unidimensional when dealing with the evaluation of any one facet of job satisfaction and is multidimensional when dealing with more than one facet. Affective job satisfaction is a subjective construct representing the emotional feelings of an individual, which further reflects the degree of happiness of the employee about their job (Spector, 1997; Thompson \& Phua, 2012; Moorman, 1993; Kalleberg, 1977). Income, working environment and promotional opportunities are the main factors, and age, tenure and gender are the main contributors of job satisfaction (Fritsche, 1996).

\subsection{Job Satisfaction in the Views of Different Researchers}

There is no permanent and accurate definition of job satisfaction in the world; it varies from person to person, organization to organization, country to country and culture to culture. Although there might be some international trends, such as the notion that teachers are most satisfied due to the intrinsic role of teaching, the achievement of students, the positive relationship with all stakeholders, helping the students, self-growth and development (Dinham \& Scott, 2002; Vandenberg, 2002) and the context that seems to be the most powerful predictor (Dinham \& Scott, 1999, 2000a, 2000b). However, different authors, experts and researchers have discussed the different definitions as: job satisfaction is a combination of psychological, physiological and environmental circumstances that cause a person truthfully to say they are a satisfied employee (Hoppock, 1935), which presents a set of factors that cause a feeling of satisfaction. Job satisfaction is an effective orientation for individuals towards the work roles that they presently occupy (Vroom, 1964). It is a way of feelings of people about their job and its various aspects depending on likeness or dislikeness of people (Spector, 1997). Job satisfaction is a combination of positive and negative feelings that employees have towards their jobs, which are closely linked to their behaviour in the workplace (Davis \& Nestron, 1985). Job satisfaction is a worker's sense of achievement and success, which is directly linked with productivity and personal wellbeing. It further implies enthusiasm and happiness, which leads to recognition, income, promotion, achievement and feelings of the fulfillment of goals (Kaliski, 2007). Job satisfaction is a process of contentment with the rewards of their job, particularly in terms of intrinsic motivation (Statt, 2004). Positive, favourable attitude and feelings related to job satisfaction; negative, unfavourable attitudes and feelings relate to job dissatisfaction (Armstrong, 2006). Job satisfaction is the collection of feelings, beliefs and attitudes about the job, especially about work and its kinds, co-workers, supervisors, subordinates and pay (George \& Jones, 2008). Job satisfaction is complex and multifaceted, and means different thing to different people (Mullins \& Lineham, 2006). It is more than an attitude and interval state, and is associated with personal feelings of achievement, either quantitative or qualitative (Mullins, 2005). Job satisfaction refers to the feelings of perception, which means the job meets the person's material and psychological needs (Aziri, 2008), but unfortunately job satisfaction still has not received proper attention and importance in the eyes of researchers and scholars, plus heads and managers of various organizations, (Aziri, 2011).

The purpose of this study is to acquire a greater understanding of TEs' perceptions, experiences, and attitudes to their job and discover the major factors relating to their job satisfaction in the teacher education departments at the universities in the Sindh Province of Pakistan. The issue of job satisfaction is growing more serious day by day because the significant quality implications are directly connected with it, and quality education leads to economic development in a country. Much of the research on job satisfaction is done in a Western context, so it is still unclear what and how TEs feel about their job and workplace in a Pakistani context. Therefore, it is important to replicate job satisfaction research in Pakistan in order to test the generalizability of Western organizational theories; to disclose the real condition of job satisfaction of TEs; to add to and fill the gaps in the available literature at national and international levels; and finally to explore the ideas and factors that influence organizational culture among teacher education institutions and universities.

\subsection{Background of the Study}

The education sector plays a vital role in and performance the core tasks of any nation and state so progress and 
development can be achieved. Education brings change not only in technology and labour market patterns, but also in people's lives through education, which in return can change the global environment. The Pakistani education system reflects and strengthens its social, cultural and moral values, which are based on the core values of religion and faith (National Education Policy [NEP], 2009). Furthermore, the literacy rate in Pakistan is 58\% where (46\% female; 69\% male) which was 57\% in the survey of 2008-2009 (Pakistan Survey, 2010-2011). As we know, education is the backbone of any country, which is why, it is important for governments to make good, practical, realistic and implementable policies for the betterment of the education system in their countries. Therefore, an autonomous body the Higher Education Commission (HEC) was established by the Federal government of Pakistan to bring in radical reforms and meet the international higher education levels in Pakistan (Malghani, 2012). Under HEC, there are 177 degree-awarding universities and institutions, of them, 103 are public and 74 are private. There are 20 public sector and 29 private sector universities and degree-awarding institutions, working in the Sindh Province, to impart education in the fields of medicine, engineering, agriculture, veterinary sciences and general disciplines. Out of 20 public sector universities there are 6 general universities and 1 business degree-awarding institute (HEC), where 14 teacher education departments are working in order to produce teachers and TEs to cater to the needs of the education system in Sindh Province, which consists of urban and rural areas with huge populations.

\section{Literature Review}

Recently, a number of studies have been carried out in many developed countries on the job satisfaction of teachers, which show the teachers'-work intensification (Hargreaves, 1994) and mirror the societal trends towards the overworking of teachers (Naylor, 2001). Furthermore, a list of common facets comprised of appreciation, communication, co-workers, fringe benefits, job conditions, nature of work, organization, personal growth, policies and procedures, promotion opportunities, recognition, security and supervision reveal the different aspects of a job where the individual must be satisfied (Spector, 1997). Job satisfaction can be seen also within the broader context, such as the range of different issues that affect the employee's experience of work, the quality of work, the quality of their working life and their relationship with staff, superiors and subordinates. Furthermore, job satisfaction can be understood in terms of its relationship with other key factors, such as general wellbeing, quality of life, stress at work, stress at organizational matters, control of things, work and social life (Tomazevic, Seljak \& Aristovnik, 2014) of employees in their working organization. Most of the employees in Indian industries are not satisfied with their jobs with the exception of a few, such as males in the commerce sector and females in the education sector, which indicates that the total job satisfaction level in the manufacturing sector is very low (Kumari, Joshi \& Pandey, 2014). Job satisfaction is one of the most extensively researched subjects in industrial or organizational psychology and behaviour (Judge \& Church, 2000). That is why many job satisfaction and motivational theories have been made to study the job satisfaction of employees in different sectors and organizations. Since job satisfaction can be linked with productivity, motivation, regularity, absenteeism, accidents, mental health, physical health and general life satisfaction (Landy, 1978), it indicates a person's individual wellbeing, which is a very significant aspect to research (Judge \& Klinger, 2007). Job satisfaction has emotional, cognitive and behavioural components, which comprise boredom, anxiety and excitement; beliefs and feelings; and demanding and challenging work-related actions, such as being tardy, staying late and avoiding of work (Bernstein \& Nash, 2008). There are two types of job satisfaction: global job satisfaction, which depends upon an employee's overall feelings about their job; and job facet satisfaction, which depends upon on employee's feelings about specific job aspects, such as salary, benefits, and quality of available resources (Muller \& Kim, 2008). These help to measure the specific aspects of the job that are required for improvement (Kerber \& Campbell, 1987). A happy employee is a productive employee (Syptak, Marsland \& Ulmer, 1999) and causality may flow in the opposite direction (Bassett, 1994) depending on the productivity of work which leads them to satisfaction. Happy employees do not negatively affect productivity, but they can have a positive effect on an organization and society; therefore, it still benefits all stakeholders to have happy and satisfied employees. In reality, employees become satisfied when they enjoy the working environment in their organization (Berry, 1997). Job satisfaction is very much subjective for each employee and each organization. That is why each and every situation needs to be assessed. Job satisfaction causes a series of influence on the organization and its employees. It directly influences employee productivity, loyalty, thinking, perception and absenteeism. It has been proved that the higher the degree of job satisfaction the higher the level of employee loyalty (Vanderberg \& Lance, 1992).

There are three important features of job satisfaction:

1. Organizations should be guided by human values and should treat workers fairly with respect. The assessment of job satisfaction may serve as a good indicator of employees' effectiveness because a high level of job satisfaction may be a sign of good emotional and mental states of employees. 
2. The behaviour of employees depending on their level of job satisfaction, will affect the functioning and activities of the organization's business and progress. It has been calculated that satisfaction will result in positive behaviour, and dissatisfaction will result in negative behaviour.

3. Job satisfaction may serve as an indicator of organizational activities, and its evaluation system can be defined because it will boost the performance of employees and organizations (Spector, 1997).

As the education sector holds the important position of bringing radical reforms for the development of the nation, it is necessary for the education sector to have highly skilled, motivated, hardworking, committed, dedicated and high-quality staff to achieve its targets. On the other hand it is necessary to check the condition of staff, their working environment, working relationships, etc. to insure that the employees, especially the teachers or TEs are satisfied with their job because satisfied teachers and TEs can bring radical reforms for any development in a country through utilizing their knowledge and skills. Knowledge has power, which controls access to opportunities and advancement, and permits a country to stand on its own feet (Ducker, 1997). Furthermore, if we want to know the organization's health, progress and quality of work, it can be visible only through the canvas of job satisfaction, which largely depends upon the human resource (Crossman \& Abou Zaki, 2003). A satisfied employee can work more hours with better efficiency and interest compared to an unsatisfied employee. Unsatisfied academic staff would not perform at their best and quite likely try to change the organization or may be the profession of teaching. It is important to study the facets of job satisfaction that have an effect on the retention of teachers and their development conditions. Teachers who were preparing to leave their profession had a more negative attitude towards teaching as a career due to less satisfaction or totaly dissatisfaction (Smith, 2007). As their perception about their job was not meet with their state of mind determined by the extent (Evans, 1997). The present study shows a moderate to strong relation between all the tested elements of job satisfaction, although the pay benefits show a weak but significant relation to job satisfaction. It was also suggested that decision making bodies should make employee friendly policies (Sohail \& Delin, 2013)

\section{Methodology, Philosophical Assumptions and Research Questions}

The study followed by qualitative design that was depending on philosophical assumptions, epistemologies, and ontologies (Crotty, 1998), underpinned by the interpretivism that ontological relativism; that is, reality is multiple, created and mind-dependent, and epistemological constructionism; that is, knowledge is constructed and subjective, (Creswell, 2009). After gaining ethical approval and letters for the heads of the organizations and departments from the Office of the Dean, Philosophical Faculty, University of Eastern Finland, Joensuu, the researcher left Sindh, Pakistan where he was to collect data. The fieldwork began in December, 2014 to March, 2015, in order to gain firsthand and primary data from the TEs of the departments, institutes and faculties of education at the universities of the province. After gaining permission from the heads and the consent of the TEs, the interviews were conducted with TEs one by one at their respective departments. The research questions were constructed in this way: (a). What is the perception of TEs about their job and job satisfaction? (b). What is the level of TEs job satisfaction? (c). What are the dimensions of job satisfaction of TEs and how do they affect their job and their job satisfaction level?

\subsection{Participants and Methods}

Participants were recruited and the sample was created to assess the utility of the study from multiple perspectives to be close and closer through the sample of friends of the friends (Snow ball) to collect in-depth, true and real data. For this purpose, the friends were scheduled to be interviewed and after the interview they were asked to suggest their friends from any other department and to call those friends to arrange time for their interview. In this way, over time we managed to get enough people to agree to be interviewed at different departments of different universities. Data were collected through semi-structured in-depth interviews and were then analysed and categorized by content analysis, using qualitative techniques. The data of all interviews were confidential and the identity of the participants was protected. The nature of content studies is connected with both epistemological and methodological aligned (Shaw \& Gould, 2001). The philosophy of content research is based upon the notion that it is not only a conveyance of individuals' subjective experiences but also a procedure of reintegration for those who had lived through difficult situations and traumatic events (Riessman, 1993). Qualitative research is better suited to delineate the personal meanings of the narrated experiences of the participants without losing the richness and genuineness of the responses (Flick, 1998; Strauss \& Corbin, 1998). For this study qualitative data and snowball sampling techniques were used to select the sample totaled 40 TEs (19 male; 21 female). Among these TEs, 18 were $\mathrm{PhD}$ ( 8 male; 10 female); 10 were MPhil (5 male; 5 female); 12 were MEd (6 male; 6 female). There were 6 professors ( 1 male; 5 female); 1 male associate professor, 19 assistant professors ( 8 male; 11 female); and 14 were lecturers (9 male; 5 female). The age of 
the participants' group was from 28 to 58 years with a mean average of 44.65 . The majority (89\%) was married and (11\%) single; $53 \%$ had urban domicile and $48 \%$ had rural domicile.

An interactive process between the researcher and the participants was intended with the participants' words and observable behaviour to be used as the primary data (Marshall \& Rossman, 1999). Through the process of elicitation and the interpretation of expressions and behaviours, the perceptions of both male and female TEs were investigated deeply. In employing these assumptions, the authors aimed to explore, explain and describe the similarities and differences among male and female TEs' ideas, understanding and feelings towards job satisfaction.

\subsection{Procedure of Data Collection and Interviews}

In the Sindh area, there are large universities, such as the University of Sindh (UoS), Jamshoro/Hyderabad; the University of Karachi (UoK); and the Shah Abdul Latif University (SALU), Khairpur. Also there are, the small or newly established universities and institutions, such as the Benazir Bhutto Shaheed University (BBSU), Lyari Karachi; the Sindh Madressatul Islam University (SMIU), Karachi; the Shaheed Benazir Bhutto University (SBBU), Nawabshah; and the Sukkur Institute of Business Administration (SIBA). Data collection started from the Sukkur IBA and ended at the Department of Educational Management and Supervision (EMS), Faculty of Education, UoS. As the TEs were reluctant for audio recording in their interviews, so their said themes and important sentences were recorded during their interview and written in interview protocol proforma. After each interview, the important observations were recorded in detail on the last pages given in the same proforma and the transcription was made after the completion of every interview. The transcription of the majority of interviews was up to three typed pages in Microsoft Word using as 12 Times New Roman, 12-point font size with 1.5 line spacing. The interviews were conducted in the Sindhi, Urdu and English languages as per the wishes, expertise and needs of the participants and the researcher. The main aim of conducting in-depth semi-structured interviews was to explore the perception, experience level and dimensions of the job satisfaction of TEs. The items of interview were formulated from an extensive literature review, personal experience and observations of the researchers at different teacher education institutions of the country. This observation depended on more than three years of time period. The consent form, content, questions and interview guide were developed and reviewed by an expert (supervisor). The first five interviews were conducted at the beginning of the study as a pilot for testing the tools in order to understand the language of the participants, the variety of questions and sub questions. The interview style was finalized for further fieldwork. The content of structured interviews is easy to analyse and is fairly objective (Hitchcock and Hughes, 1989); the average duration of each interview was 30 to 40 minutes.

\subsection{Data Analysis and Validity}

An inductive thematic analysis was conducted on transcripts using a six-phase procedure described by Braun \& Clarke (2006). As mentioned, after every interview, data were fully transcribed. The codes were then generated and converted into potential themes, then those potential themes and relevant data were merged and all transcripts themes and data were reviewed. Finally, all transcripts, themes and data were refined and combined into larger themes. For validity, the study was guided by a relativist approach, which means the criteria for judging the quality of qualitative research could be drawn from an ongoing list of the characterizing traits (Sparkes \& Smith, 2009, 2014). The list included: the worthiness of the topic; the significant contribution of the work; rich rigor; a selection of samples for the appropriate purpose of the study; the generation of data, which could provide meaningful and significant claims; the coherence of research, which refers to how well the study hangs together in terms of the purpose; the methods; and the results (Tracy, 2010). For enhancing the quality of our research work, the audit trail (i.e., independent scrutinized data collection and theoretical matters) and aimed for resonance (e.g., naturalistic generalizations) were taken in to consideration.

\section{Results and Discussion}

The majority of TEs (72.5\%) were very clear about their job and job satisfaction. Their data revealed that the job was a combination of rights, duties and responsibilities, where rights can be enjoyed when the duties and responsibilities are properly fulfilled. Job satisfaction was a process in which the TEs felt relaxation, peace and security within their souls and minds after performing their duties and responsibilities to serve their communities, society and nation to lead them towards education and knowledge, character building, human values and economic development.

The job satisfaction level has been divided in to three levels from the revelation of the collected data from TEs: (a). a high level of satisfaction, depending on their satisfaction with the majority of facets of job satisfaction available in their department (47.5\%) (b). a moderate level of satisfaction, depending on their satisfaction with some of facets of 
job satisfaction available in their department (35\%) and (c). a low level of satisfaction, depending on their satisfaction with few of facets of job satisfaction in their department (17.5\%). Teachers' job satisfaction levels are very high and have a positive effect on meeting the educational aims. It is expected that the teachers with a high level of job satisfaction give qualified education and bring up successful students (Demirtas, 2010) in their institutions, community and society. Low level satisfaction is expected to correlate with the outcomes of work stress a psychological distress and low self-esteem (Ho \& Au, 2006). The majority of TEs with high and moderate levels of satisfaction were found in large universities of the Sindh Province, as job satisfaction was the product of attitudinal and affective responses of teachers (Ho \& Au, 2006), where they had a flexible system of monitoring and evaluation, full job security, no fear of being fired, good monetary benefits, a suitable pension and a gratuity system.

The following broad themes have been identified from the interviews with TEs:

\subsection{Work, Assignments and Workload}

The majority of TEs (67.5\%) were satisfied with their normal or less work load; co-curricular activities and events celebrations; work and struggle for quality education, as revealed in the following information from the interviews.

Work is to teach sometimes two or three subjects in a semester. Most of the subjects are allotted at the wish of the TEs, but sometimes a new subject(s) is allotted to a few of the TEs to teach because there is no expert faculty available to teach that subject. In our eight years service we observed once or twice that some TEs were given new subjects, otherwise they would teach the same subjects for five years or more. Very few TEs accepted new assignments to do extra work other than their subjects, but those are the most junior and newly appointed. If most senior TEs accept any other assignment than their teaching they demand one assistant to help them as a subordinate. There is a big phobia of superiority of seniors, which is why junior TEs like to sit, discuss matters and work together (From the majority of TEs at Large universities).

We always receive new instructions for new and extra assignments except teaching the subjects. Very few people get allotted the subjects that they wish for and have the expertise for. First seniors and influential TEs are allotted the subjects they want and then others get the remaining subjects. Even the time and the timings are set down as per the wishes of the influential ones. Four or more subjects are allotted to all TEs except then influential and senior TEs. But still we are satisfied with our job because the salary is the only source of our income to meet the day to day expenses of our families (From the majority of TEs at small and newly established universities).

Data further revealed that the main reason for the satisfaction of TEs at large universities is that they have work that is relevant to their qualification, expertise and field of interest. They have hardly two subjects to teach, which means six credits per week. They do not spend much more amount of time on the preparations before teaching because their teaching style can be traditional depending on the lecture method. Among the satisfied TEs, the majority are from large universities where they enjoy their limited work and the laissez-faire management of their department, faculties and institutes.

\subsection{Opportunities for Advancement, Growth and Development}

The majority of TEs (52.5\%) were satisfied with the opportunities for professional development, growth and promotions as these reports from the interviews show.

Those TEs who frequently visit the office of heads get good opportunities of advancement, growth and development even they are not much more competent than many other TEs in the department. They go for different trainings and workshops to represent the department, faculty and university, and on their return they never share anything with their colleagues and friends; they even hesitate to share that they had gone for any training or workshops. Other TEs are given very few chances for any training and workshops, the opportunities occur only once or twice in two to three years. Scholarships with full pay and stipend are awarded to TEs after the recommendations of the heads of the departments, faculties and institutions, which is a very hectic process and routine. However, these all become easier and are done within a few days for those who are in the good books of the heads. The TEs or employees who are in their good books never work hard for the students and for the institutions; they just work hard on the environment, and their main work is to make the heads happy through supporting them at every platform inside or outside the universities. However, the real and hardworking TEs have tried to improve and prepare themselves for every challenge in their professional life. That is why they have become more satisfied with their jobs and lives, (From the majority of TEs).

The participants revealed that it was very difficult to get any opportunities of advancement, growth and development on the basis of merit and due to the autocratic management of the heads and the constant statements of the lack of finances and the weak financial position of the organization, many TEs are rarely sent to conferences, training and 
workshops. because the few good opportunities are awarded to those TEs who are close to heads of departments, faculties and the organizations. There is no transparency, and injustice is faced by many TEs. Promotions are also very limited; many TEs with doctorates have been waiting for their promotions for five or more years due to the autocratic and uninterested management or the administration style and attitude. The management of universities seems to have no capacity to listen to criticism of their planning, policies and routines. If any TEs do criticize, they are considered to be the bitterest enemies of the organization and face a lot of hurdles and problems.

\subsection{Financial and Fringe Benefits}

The majority of TEs (60\%) were satisfied with good salaries, grades and status; a loans facility; additional paid work or financial support; fringe benefits; leave encashment; allotment of houses, hostels and residential pilots; a gratuity and a pensionable job as revealed in the interviews.

TEs that are in the good books of heads are given different opportunities to earn more and acquire more financial benefits. They are given evening classes to teach for extra pay, duties inside and outside the universities for which they get extra pay. These TEs do evening duties, attend their MPhil or PhD classes and do some other paid duties at the same time even if they have classes to teach in the morning and the evening. Because they are the favorites of the heads, they have no bondage and are not bound to abide by any rules and regulations. Many times this situation and other misuse of powers, rules and regulations have been highlighted to the heads of the universities in the form of complaints, but no action or notice has been taken against these types of favours and the consequent injustice, (From the majority of TEs).

Data have further revealed that large universities have well-enough established systems to provide good benefits to their employees and TEs. But the small and newly established universities have weak newly established systems to facilitate their employees and TEs with some financial and fringe benefits. Large universities have evening programmes where their teachers can teach and get extra financial benefits per month and maybe per course. They have very good housing units for their employees which are allotted them as per their grade and scale for their families. They also have good hospitals on their panel for their employees, where employees and their families go for medical treatments.

\subsection{Supervisor Support, Permission and Free hand}

The majority of TEs (57.5\%) were satisfied with the self-motivated and energetic leadership and had a positive attitude regarding the administration at their department level; a proper feedback system; appreciation; and good relationship with leadership and management with regards to their immediate boss or supervisory level as revealed in the interviews.

The supervisory support is that you do your work and do not disturb others, which is a Laissez-faire management style that is prevalent in most of the departments of large universities. The main rule of these departments is that whenever TEs do anything they do it on their own and just inform their immediate boss. The good and selected practices are praised in front of the heads of the organization and are appreciated, but nothing is persued to set up a proper system for future development (From the majority of TEs in large universities).

We are instructed to plan everything in advance, discuss it with head of the department, faculty and university and then get instructions to finalize the plan. Finally permissions needs to be acquired for doing anything as per finalization of the plan, where no little freedom is given to TEs to move towards new practices, innovations and maybe creations. Only instructions have been received every time and most of the time we were remind that our main responsibility is teaching, then research, training, project development, which means we are working on multiple areas. It is a very hectic and hassle basil type of work (From the majority of TEs of small and newly established universities).

Data further revealed that supervisory support, permission and a free hand is vice versa at higher levels of administration at large universities, which does not negatively effect the job satisfaction level of TEs. However, in small and newly established universities, everything must be done with the permission of the higher authorities of the universities. Therefore, sometimes permission is given in time, but sometimes it is not. In large universities, the Laissez-faire management can have a positive or negative effect on the job satisfaction level and achievement of organizational goals. It is said that the heads who adopt the laissez-faire style of leadership may be considered to exert very little influence on the specific circumstances and situations of any organization, which potentially affects the morale of teachers, their job satisfaction and motivation (Evans, 1997). Furthermore, it can be said that the relationship between supervisors and TEs depending partially on functional attraction refers to extent that subordinates perceive from their supervisor depends on help that value outcomes. The expectation of subordinates 
revolves around the moral support from their heads, which satisfied them at their office and work (Locke, 1976; Cranny, Smith \& Stone, 1992).

\subsection{Working and Sympathetic Relationships}

The majority of TEs (75\%) were satisfied with working relationship and sympathetic relations at the work place as shown in the interviews.

We have good social relations in our department and support each other in taking classes as replacement to save students time because they come from faraway places too. We arrange different gatherings and parties to celebrate happy moments and events at the department level. We even support each other in our personal life situations and attend most of the ceremonies of our colleagues whenever we are invited. Most of the time we have tea and lunch together for our socialization at the department level (From the majority of TEs of large universities).

We enjoy having our tea and lunch breaks together and we arrange welcome and farewell parties for our department students and participate actively with our students. We give ethical permission to our students to have any drama and parody on any of their teachers. We exchange classes, assignments and support each other. We share and discuss some things with each other, too (From the majority of TEs of small and newly established universities).

The data further revealed that TEs are also satisfied in building social relations or contacts. They have self-respect and good working relationships, enjoying meeting with national and international scholars, students' satisfaction relating to social relationships, counseling and guidance are important to TEs as are humanitarian and religious mission, status, respect in society, dignity and social services. All of these things are very attractive to the majority of TEs and are the main source of their job satisfaction. Also, most of the TEs support each other in different critical situations in their professional and personal lives.

\subsection{Available Facilities and Working Environments}

The majority of TEs (55\%) were satisfied with the available facilities and the working environment as shown in the interviews.

We have a good working environment because no one disturbs us in our own work. Whatever we do we plan ourselves and share with our students and perform in our classes. We have a transport facility that picks up us from and drops us off at our homes. Faculty politics supports most of the faculty members in solving their problems at the department and university levels. We have job security that really plays a very important role in appreciating our work at the university; it also supports our mental and life satisfaction. We come and go from our department at flexible times and in relaxed manner. We also have a short duration of work; for example, from 9 AM to 2PM. Our jobs are non-transferable and we have a good spread of vacations in winter and summer. The most important thing is that we have a employee-children quota in admission in all departments of the university (From the majority of TEs of large universities).

We have a good working environment because our students remain satisfied, which is enough for us. We have a transport facility that picks us up and drops us back at our homes. We don't have job security, which is really disturbing to us sometimes and it also has negative effect on our mental states and life satisfaction. We have a very strict and long working day from 9 AM to 4or 5 PM. Our job is non-transferable, but we don't have decent vacation times in winter and summer. Most importantly we can't get leave without really strong reasons (From the majority of TEs of small and newly established universities).

Data further revealed that satisfaction with the facilities and environment brings the satisfaction of TEs towards a conducive working environment. Among those facilities and environments the availability of updated resources; accommodation; transport; 24-hour office access; tactful discipline; freedom to work; faculty politics; an interesting and respectable profession; job security; mental life satisfaction; flexible, relaxed timing and short duration of work; a non-transferable job; the availability of winter and summer vacations; employee-children quota in admissions in university and home city posting.

\section{Conclusions}

On the basis of the analysis and interpretation of the collected data, we conclude that an average of $61 \%$ of TEs was satisfied with their jobs. Specifically, $75 \%$ were satisfied with their working relationships and sympathetic relationships, which remained priority to achieve job satisfaction; $67.5 \%$ prioritized work, assignments and workload; $60 \%$ prioritized financial and fringe benefits; $57.5 \%$ prioritized supervisor support, Permission and free hand 55\% prioritized available facilities and working environments and 52.5\% prioritized opportunities for advancement, 
growth and development. We also conclude that the findings of this study revolve around and support the theories of Maslow's (1995) needs hierarchy theory and Herzberg's (1966) two-factor theory, which is also known as the motivator-hygiene theory, as the factors of job satisfaction are found in salary, academic qualification, career prospects, supervision, management, working environment and culture (Tasnim, 2006). Maslow's needs hierarchy theory supports one of the first theories of job satisfaction. The theory suggests that human needs consist of levels of physiological need, safety, belongingness or love, self-esteem, and self-actualization. It postulates that there are essential needs to be met first on a priority basis, which are physiological needs and safety; and that before more complex needs the belonging and esteem needs should be fulfilled. Herzberg's two-factor theory states that satisfaction is driven from motivation and hygiene factors related to work. An employee's motivation to work is directly and continually related to the satisfaction of related human and material resources, which can be seen as an inner force that drives individuals to attain personal and organizational goals (Hoskinson, Porter \& Wrench, 1998). Furthermore, the inductively identified six themes also support the model of Smith, Kendall \& Hulin, (1969) and Tran Kim Dung, (2005). They also supported by the findings, such as work itself, pay, promotion and supervision, which are the main dimensions of the job that represent the most important characteristics that people have affective responses, (Hulin, 1991). The data and the researchers observations revealed that TEs were more satisfied with a normal workload, an attractive salary and other financial benefits, freedom in class and their department, a democratic system of evaluation and style of management, facilities in which to complete their work in the prescribed time, socialization in their department, fairness, transparency, and social relationships with their colleagues and students.

The study indicates the importance of the exploration of the dimensions of job satisfaction of TEs from their interviews data. It is generalized that the founded factors and dimensions effect very well on the job and the workplace context of TEs of the universities of Sindh province. The thematic analysis shows that the various dimensions of job satisfaction are very clearly link with the professional lives of TEs all over the province. However, it is suggested that some further studies with different methods and techniques need to be conducted to explore many more dimensions, which would explain a high degree of job satisfaction and its related dimensions. Teachers enter into university teaching for their intellectual pleasure (Altbach \& Lewis, 1996) and they enjoy their work to receive satisfaction (McKeachie, 1982; Serow, 2000) as a sustained matter of priority in life. The findings of this study will support all stakeholders such as department heads, policy makers, educational leaders and managers, TEs and government officials. It will help them to understand and take this phenomenon seriously and make the necessary resources available to enable TEs and other concerned staff members to cope with their problems as they work for their satisfaction and to bring radical reforms through proper implementation of policies and procedures, which will lead them towards quality education in their respective institutions.

\section{Acknowledgements}

We wish to acknowledge the participation of all TEs of the universities of the Sindh Province of Pakistan, who gave their time and contributed their valuable perceptions, experiences and reflections in the data collection process for our research study.

\section{References}

Altbach, P.G., \& Lewis, L.S. (1996). The academic profession in international perspective. In: P.G. Altbach, (ed.). The international academic profession: Portraits from fourteen countries. Princeton, NJ: The Carnegie Foundation for the Advancement of Teaching.

Armstrong, M. (2006). A handbook of human resource management practice, (10 ${ }^{\text {th }}$ ed.). London, England: Kogan page publishing.

Aziri B. (2011). Job satisfaction: A literature review, Management Research and Practice, 3(4), 77-86.

Aziri, B. (2008). Human resource management, job satisfaction and motivation of employees. Gostivar, Macedonia: Tringa Design.

Bassett, G. (1994). The case against job satisfaction. Business Horizons, 37(3), 67.

Bernstein, D.A., \& Nash, P.W. (2008). Essentials of psychology (4 $4^{\text {th }}$ ed.). Boston, MA: Cengage Learning.

Berry, L., M. (1997). Psychology at work. San Francisco, CA: McGraw-Hill Companies, Inc.

Braun, V., \& Clarke, V. (2006). Using thematic analysis in psychology. Qualitative Research in Psychology, 3(2), 
77-101. http://dx.doi.org/10.1191/1478088706qp063oa

Cranny, C.J., Smith, P.C., \& Stone, E.F. (1992). Job satisfaction: How people feel about their jobs and how it affects their performance. New York, NY: Lexington Books.

Creswell, J.W. (2009). Research design: Qualitative, quantitative and mixed methods approaches, ( $3^{\text {rd }}$ ed.). London, England: Sage Publications.

Crossman, A., \& Abou-Zaki, B. (2003). Job satisfaction and employee performance of Lebanese banking staff. Journal of Managerial Psychology, 18(4), 368-376. http://dx.doi.org/10.1108/026839403104731

Crotty, M. (1998). The foundations of social research: Meaning and perspective in the research process. London, England: Sage Publications.

Davis, K., \& Nestrom, J.W. (1985). Human behavior at work: Organizational behavior, ( $7^{\text {th }}$ ed.). New York, NY: McGraw Hill.

Demirtas, Z. (2010). Teachers’ job satisfaction levels. Procedia-Social and Behavioral Sciences, 9, 1069-1073.

Dinham, S., \& Scott, C. (1999). The relationship between context, type of school and position held in school and occupational satisfaction, and mental stress. Paper presented to the Australian College of Education/Australian Council for Educational Administration, National Conference. Darwin, NT: Australia.

Dinham, S., \& Scott, C. (2000a). Moving into the third, outer domain of teacher satisfaction. Journal of Educational Administration, 38, 379-396. http://dx.doi.org/10.1108/09578230010373633

Dinham, S., \& Scott, C. (2000b). Teachers' work and the growing influence of societal expectations and pressures. Paper presented to the American Educational Research Association Annual Meeting, New Orleans, LA.

Dinham, S., \& Scott, C. (2002). The international teacher 2000 project: An international study of teacher and school executive satisfaction, motivation and health in Australia, England, USA, Malta and New Zealand. Paper presented to the Challenging Futures Conference, University of New England, Armidale, NSW, Australia.

Drucker, P.F., \& Nakauchi, I. (1997). Drucker on Asia: Dialogue between Peter Drucker and Isao Nakauchi. Tokyo, Japan: Diamond Inc.

Evans, L. (1997). Teacher morale, job satisfaction and motivation. Thousand Oaks, CA: Sage Publications.

Flick, U. (1998). An introduction to qualitative research. London, England: Sage Publications.

Fritsche, K. (1996). Job satisfaction of Texas dietician. UMI.

George, J.M., \& Jones, G.R. (2008). Understanding and managing organizational behaviour, (5 ${ }^{\text {th }}$ ed.). Englewood Cliffs, NJ: Pearson/Prentice Hall.

Hargreaves, A. (1994). Changing teachers, changing times. London, England: Cassell.

Herzberg, F. (1966). Work and the nature of man. Cleveland, OH: World Publishing Company.

Higher Education Commission. (2015). Retrieved from http://www.hec.gov.pk/Ourinstitutes/pages/Default.aspx

Hitchcock, G., \& Hughes, D. (1989). Research and the teacher. London, England: Routledge.

Ho, C.L., \& Au, W.T. (2006). Teaching satisfaction scale: Measuring job satisfaction of teachers. Educational and Psychological Measurement, 66, 172-185. http://dx.doi.org/10.1177/0013164405278573

Hoppock, R. (1935). Job satisfaction. New York, NY: Harper and Brothers.

Hoskinson, Porter \& Wrench (1998). Personal and organizational goals, p.133.

Hulin, C.L. (1991). Adaptation, persistence, commitment in organizations. In M. Dunnette \& L. Hough (Eds.), Handbook of industrial and organizational psychology ( $2^{\text {nd }}$ ed., pp. 445-507). Palo Alto, CA: Consulting Psychologists Press.

Hulin, C.L., \& Judge, T.A. (2003). Job attitudes. In W.C. Borman, D.R. Ilgen, R.J. Klimoski, \& Weiner, I.B. (Eds.), Handbook of industrial and organizational psychology, (pp. 255-276). Hoboken, NJ: Wiley.

Judge, T.A., \& Church, A.H. (2000). Job satisfaction. In C.L. Cooper (Eds.), Industrial and organizational psychology: Linking theory with practice (166-198). Oxford, England: Blackwell.

Judge, T.A., \& Klinger, R. (2007). Job satisfaction: Subjective well-being at work. In M. Eid, \& R. Larsen (Eds.), The science of subjective well-being, (pp. 393-413). New York, NY: Guilford Publications. 
Kaliski, B.S. (2007). Encyclopedia of business and finance ( $2^{\text {nd }}$ ed.). Detroit, MI: Thompson Gale.

Kalleberg, A. (1977). Work values and job rewards: A theory of job satisfaction. American Sociological Review, 42(1), 124-143.

Kerber, K.W., \& Campbell, J.P. (1987). Job satisfaction: Identifying the important parts among computer sales and service personnel. Journal of Business and Psychology, 1(4), 337-352. http://dx.doi.org/10.1007/BF01018143

Kumari, G., Joshi, G., \& Pandey, K.M. (2014). Analysis of factors affecting job satisfaction of the employees in public and private sector. International Journal of Trends in Economics Management and Technology, 3(1), $1-19$.

Landy, F.J. (1978). An opponent process theory of job satisfaction. Journal of Applied Psychology, 63, 533-547. http://dx.doi.org/10.1037/0021-9010.63.5.533.

Locke, E.A. (1976). The nature and causes of job satisfaction. In M.D. Dunnette (Ed.), Handbook of industrial and organizational psychology, (pp.1297-1349). Chicago, IL: Rand McNally.

Malghani, A. (2012). Province wise HEC accredited universities / degree awarding institutes. Retrieved from http://www.hec.gov.pk/InsideHEC/Divisions/LearningInnovation/Documents/PROVINCE\%20WISE\%20UNIV ERSITIES\%20IN\%20PAKISTAN.pdf

Marshall, C., \& Rossman, G.B. (1999). Designing qualitative research (3 ${ }^{\text {rd }}$ ed.). London, England: Sage Publications.

Maslow, A. (1995). Motivation and Personality. New York, NY: Harper.

McKeachie, W.J. (1982). The rewards of teaching, In Bess, J. (ed.), New directions for teaching and learning: Motivating professors to teach effectively, (Vol: 10, pp.7-13). San Francisco, CA: Jossey-Bass.

McManus, K. (2003). How deep is your talent pool? Industrial Engineer, 35(24).

Moorman, R.H. (1993). The influence of cognitive and affective based job satisfaction measures on the relationship between satisfaction and organizational citizenship behavior. Human Relations, 6(6), 759-776. http://dx.doi.org/10.1177/001872679304600604.

Mueller, C. W., \& Kim, S. W. (2008). The contented female worker: Still a paradox?. In K. A. Hegtvedt \& J. Clay-Warner (Eds.), Justice: Advances in group processes, (Vol: 25, pp. 117-150). Bingley, England: Emerald Group Publishing Limited. Retrieved from http://books.google.com/books?id=rynLSn6zYRkC

Mullins, J., \& Lineham, M. (2006). Desired qualities of public library leaders. Leadership and organization development Journal, 27, 133-143. http://dx.doi.org/10.1108/01437730610646633.

Mullins, J.L. (2005). Management and organizational behaviour, ( $7^{\text {th }}$ ed.). Harlow, England: Pearson Education Limited.

National Education Policy. (2009). Ministry of Education, Government of Pakistan. Retrieved from http://www.pakteachers.org/uploads/files/publications/National-EducationPolicy.pdf

Naylor, C. (2001). Teacher workload and stress: An international perspective on human costs and systemic failure: BCTF research report. Retrieved from http://eric.ed.gov/?id=ED464028

Pakistan Survey, (2010-2011). Pakistan social and living standards measurement survey. Retrieved from http://www.finance.gov.pk/survey/chapter_12/10-Education.pdf

Paterson, A. (1999). Ahead of the game: Developing academic library staff for the twenty-first century. Library Career Development, 7, 143. http://dx.doi.org/10.1108/09680819910309476

Pors, O.N., \& Johannsen, C.G. (2002). Job satisfaction and motivational strategies among library directors. New Library World, 103, 199-209. http://dx.doi.org/10.1108/03074800210433104

Riessman, C.K. (1993). Narrative analysis. Qualitative research methods series, (No. 30.). Newbury Park, CA: Sage.

Rizi, H.A., \& Kazempur, Z. (2010). A Survey on Level of Occupational Satisfaction among Managers of Iran Public Libraries Foundation in Centers of Provinces. Research on Information Science and Public Libraries, 16(1), 127-147.

Serow, R.C. (2000). Research and teaching at a research university. Higher Education, 40, 449-463.

Shaw, I., \& Gould, N. (2001). Qualitative research in social work. London, England: Sage Publications. 
Smith, W.T. (2007). Job satisfaction in the United States, embargoed for release NORC/University of Chicago. Retrieved from http://www-news.uchicago.edu/releases/07/pdf/070417.jobs.pdf

Sohail, M.T., \& Huang, D. (2013). Job satisfaction surrounded by academic staff: A case study of job satisfaction of academic staff of the GCUL, Pakistan. Interdisciplinary Journal of Contemporary Research in Business, 4(11), 126-137.

Sparkes, A.C., \& Smith, B. (2009). Judging the quality of qualitative inquiry: Criteriology and relativism in action. Psychology of Sport and Exercise, 10, 491-497. http://dx.doi.org/10.1016/j.psychsport.2009.02.006

Sparkes, A.C., \& Smith, B. (2014). Qualitative research methods in sport, exercise and health from process to product. Oxford, England: Routledge. http://dx.DOI.org/10.1080/2159676X.2013.796493

Spector, P. (1997). Job satisfaction: Application, assessment, cause and consequences. London, England: Sage Publications.

Statt, D. (2004). The Routledge dictionary of business management ( $3^{\text {rd }}$ ed.). Detroit, MI: Routledge Publishing.

Strauss, A., \& Corbin, J. (1998). Basics of qualitative research: Techniques and procedures for developing grounded theory ( $2^{\text {nd }}$ ed.). Thousand Oaks, CA: Sage.

Syptak, J.M., Marsland, D.W., \& Ulmer, D. (1999). Job satisfaction: Putting theory into practice. Family Practice Management, 6(9), 26-30. Retrieved from http://www.aafp.org/fpm/991000fm/26.html

Tasnim, S. (2006). Job satisfaction among female teachers. (Masters' thesis). Retrieved from https://bora.uib.no/handle/1956/1474

Thompson, E.R.; \& Phua F.T.T. (2012). A brief index of affective job satisfaction. Group \& Organization Management, 37(3), 275-307. http://dx.doi.org/10.1177/1059601111434201

Tomazevic, N., Seljak, J., \& Aristovnik, A. (2014). Factors influencing employee satisfaction in the Police service: The case of Slovenia. Personnel Review, 43(2), 209-227. http://dx.doi.org/10.1108/pr-10-2012-0176

Tracy, S.J. (2010). Qualitative quality: Eight big-tent, criteria for excellent qualitative research. Qualitative Inquiry, 16(10), 837-851. http://dx.doi.org/10.1177/1077800410383121

Updegraff, S. (2004). Maximizing human potential: Tips to foster personal effectiveness. Employment Relations Today, 31(1), 43-50. http://dx.doi.org/10.1002/ert.20005

Vandenberg, R. (2002). Teachers' meanings regarding educational practice. Review of Educational Research, 72(4), 577-625. http://dx.doi.org/10.3102/00346543072004577

Vandenberg, R.J., \& Lance, C.E. (1992). Examining the causal order of job satisfaction and organizational commitment. Journal of Management, 18(1), 153-167. http://dx.doi.org/10.1177/014920639201800110

Vroom, V. (1964). Work and motivation. New York, NY: John Wiley \& Sons. 